\title{
FOLIAGE INSECT DIVERSITY IN DRY EUCALYPT FORESTS IN EASTERN TASMANIA
}

\author{
by H.J. Elliott, R. Bashford, S.J. Jarman and M.G. Neyland
}

(with four tables, one text-figure and two appendices)

Elliott, H.J., Bashford, R., Jarman, S.J. \& Neyland, M.G., 2002 (31:xii): Foliage insect diversity in dry eucalypt forests in eastern Tasmania. Papers and Proceedings of the Royal Society of Tasmania 136: 17-34. https://doi.org/10.26749/rstpp.136.17 ISSN 0080-4703. Forestry Tasmania, 79 Melville St., Hobart, Tasmania 7000, Australia.

\begin{abstract}
Species numbers and composition of the insect fauna occurring on trees and shrubs were studied in dry eucalypt forests in eastern Tasmania over nine years. In all, 1164 named and putative species representing 17 orders and 157 families were collected. The bulk of the species belonged to the orders Coleoptera (28\%), Hymenoptera (25\%), Hemiptera (18\%), Lepidoptera (14\%) and Diptera (10\%). Of the species collected, 388 - about one-third - were identified at least to genus or species level. These included 21 named species not previously listed in the Tasmanian insect fauna and 90 undescribed species.

A list of 22 host plants for 171 insect species was compiled from records of 132 insect species observed feeding during the study and from previous records of insect/host plant associations for 39 insect species found on the study plots. Most insects were feeding on eucalypts (127 insect species) and acacias (38 species). The most widely distributed and commonly collected species were several well-known pests of eucalypts: Gonipterusscutellatus (Coleoptera: Curculionidae), Urabalugens (Lepidoptera: Noctuidae), Amorbus obscuricornis (Hemiptera: Coreidae), Chaetophyes compacta (Hemiptera: Machaerotidae) and Eriococcus coriaceous (Hemiptera: Eriococcidae). Host plants supporting the richest insect fauna were Eucalyptus amygdalina (74 species), E. obliqua (64), E. viminalis (46), Acacia dealbata (35), E. dalrympleana (33), E. sieberi (31), E. delegatensis (30), E. pulchella (24) and E. globulus (19).

The broad-striped ghost moth, Fraus latistria Walker (Lepidoptera: Hepialidae), was collected during the study. This species is classified as 'rare' on the list of Tasmania's threatened fauna and the collection established a new locality record.
\end{abstract}

Key Words: Insect diversity, host plants, eucalypt forests, Tasmania.

\section{INTRODUCTION}

Prior to the late 1960s, dry eucalypt forests in eastern Tasmania were selectively logged for sawlogs and small volumes of fence posts and firewood. Following the development of an export woodchip industry, large areas of these forests were harvested and regenerated by clearfelling all merchantable timber, burning the logging slash to prepare a seedbed and aerially sowing with eucalypt seed (Felton $\&$ Cunningham 1971).

The effects of forest operations associated with the woodchip industry on flora, fauna and other natural values became the subject of considerable public concern in the 1970s (Senate Standing Committee on Science and the Environment 1977) and research projects were initiated by various agencies to provide quantitative data to assist rational debate on the issue.

The invertebrates are an obvious target group for such studies because of their extraordinary species richness across a wide range of habitats and their key role in essential ecological functions including soil conditioning, nutrient cycling, pollination and biological control. There have been many investigations of individual forest insect species, particularly commercially important pests, in dry eucalypt forests, but surprisingly few studies of the species composition of the general insect fauna.

Knowledge of the insect fauna of Tasmanian eucalypt forests has been limited by the paucity of collections in some forest types and taxonomic deficiencies for many insect groups. There is a scarcity of ecological data for most of the insect fauna in these forests apart from commercially important pests (Elliott \& de Little 1984, Elliott et al. 1998) and some individual species or groups. Long-term studies of the size and composition of the forest insect fauna at specific Tasmanian sites are rare although some intensive short-term studies (1-2 years) in rainforest and wet eucalypt forests have provided valuable data on species composition. Coy et al. (1993) collected 618 species of insects from 20 orders in cool temperate rainforest, and Hickman \& Hill (1978) collected 105 named insect species and many more unidentified species from 17 orders, mainly from moss and leaf litter, in the Lower Gordon Scientific Study in southwestern Tasmania. Several studies of particular insect groups have been conducted in dry eucalypt forests in Tasmania. For example, in northeastern Tasmania, McQuillan et al. (1998) reported on the seasonality of 126 species of geometrid moths in eucalypt forests, including a dry forest site, and Bashford (1993) recorded 81 species of macrolepidoptera from dry eucalypt forests over a five-year period.

In 1978 we established a series of plots in several dry eucalypt forests scheduled for harvesting in eastern Tasmania as part of a study of the effects of clearfelling and burning on vegetation and its associated insect fauna over the long term (i.e., at least 20 years). This paper records the species diversity and host plant records of the insect fauna found on tree and shrub vegetation during the first nine years of the study. Other aspects of the study, including the effects of harvesting and regeneration on the flora and insect fauna, are being documented elsewhere. 


\section{METHODS}

\section{Plot Establishment}

Three plots were established in each of five proposed logging coupes containing mature, unlogged, dry eucalypt forest in eastern Tasmania. The location and basic descriptors of these forests are summarised in table 1 and figure 1 . Plot size was $75 \mathrm{~m} \times 50 \mathrm{~m}$ ( $0.375 \mathrm{ha})$, with the corners marked by wooden pegs and wire stakes. Within each coupe, the three plots were located to sample a range of dominant eucalypt associations usually strongly related to aspect.

Following harvesting and regeneration treatments, plots were re-established in the same locations by replacing the wooden stakes and wire pegs with permanent steel star pickets as corner markers. Due to rescheduling of harvesting operations, all plots in SW 51 and one plot in TO 54 were not harvested.

\section{Vegetation}

Mature, unlogged, dry forests in the study areas had an overstorey of eucalypt associations comprising two or more of the following species: Eucalyptus amygdalina Labill., E. obliqua L' Hèrit., E. delegatensis R. Baker, E. pulchella Desf., E. globulus Labill., E. ovata Labill., E. sieberi L. Johnson, E. tenuiramis Miq. and E. viminalis Labill. (table 1). These were relatively open forests with the stocking of mature eucalypt stems ranging from 109 to 339 stems per hectare (Elliott et al. 1991).

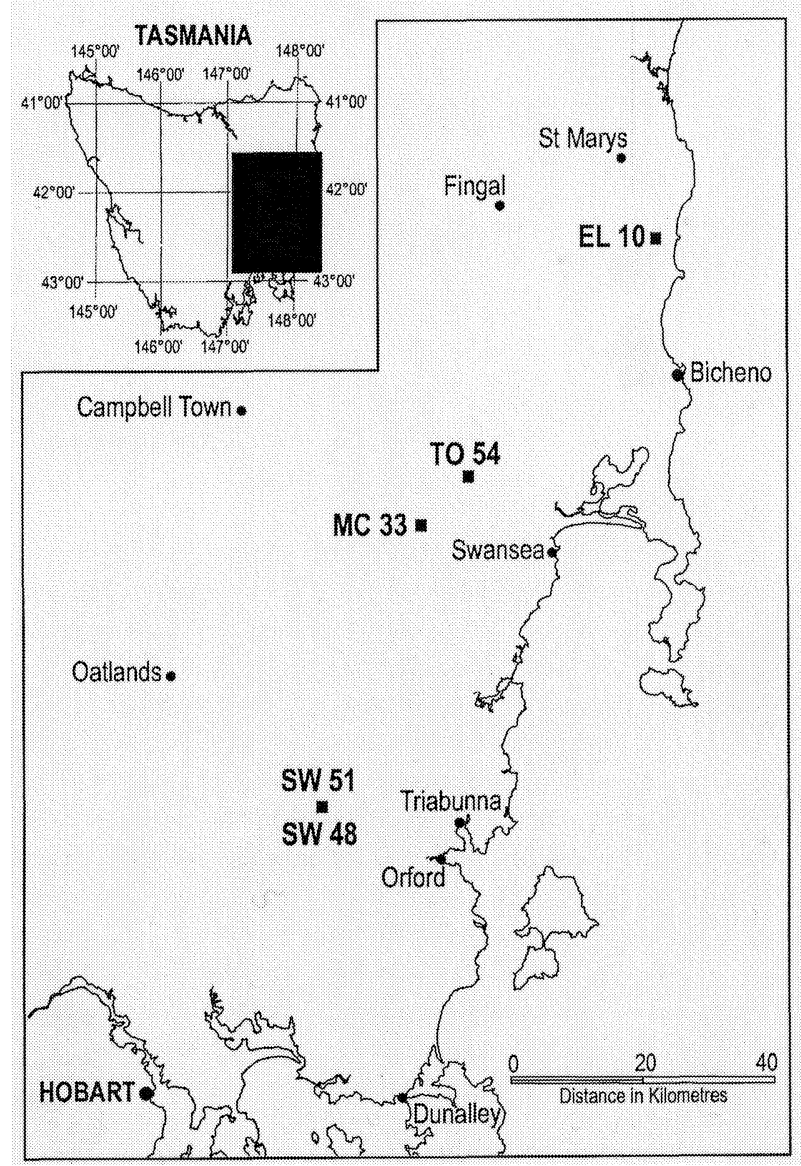

FIG. 1 - Coupe locations.

TABLE 1

Site descriptors for harvesting units (coupes) sampled for insect fauna

\begin{tabular}{|c|c|c|c|c|c|}
\hline Coupe & $\begin{array}{c}\text { Location } \\
(1: 100000) \\
\text { Tasmap ref.) }\end{array}$ & $\begin{array}{l}\text { Altitude } \\
\text { a.s.l. (m) }\end{array}$ & $\begin{array}{l}\text { Mean annual } \\
\text { rainfall }(\mathrm{mm})\end{array}$ & Parent material & $\begin{array}{c}\text { Dominant eucalypt } \\
\text { species }\end{array}$ \\
\hline SW 48 & $\begin{array}{l}\text { Nugent } \\
\text { EN } 543940\end{array}$ & 320 & 585 & Triassic sandstone & $\begin{array}{l}\text { E.obliqua } \\
\text { E.amygdalina } \\
\text { E.viminalis }\end{array}$ \\
\hline SW 51 & $\begin{array}{l}\text { Nugent } \\
\text { EN } 510965\end{array}$ & 380 & 585 & Triassic sandstone & $\begin{array}{l}\text { E.obliqua } \\
\text { E.amygdalina } \\
\text { E.viminalis }\end{array}$ \\
\hline MC 33 & $\begin{array}{l}\text { LittleSwanport } \\
\text { EP } 668392\end{array}$ & 580 & 900 & Jurassic dolerite & $\begin{array}{l}\text { E.delegatensis } \\
\text { E.amygdalina }\end{array}$ \\
\hline TO 54 & $\begin{array}{l}\text { LittleSwanport } \\
\text { EP } 762473\end{array}$ & 460 & 849 & Jurassic dolerite & $\begin{array}{l}\text { E.obliqua } \\
\text { E.tenuiramis }\end{array}$ \\
\hline EL 10 & $\begin{array}{l}\text { Break O'Day } \\
\text { FP } 030837\end{array}$ & 300 & 686 & Jurassic dolerite & $\begin{array}{l}\text { E.sieberi } \\
\text { E.obliqua }\end{array}$ \\
\hline
\end{tabular}

\footnotetext{
*Nearest meteorological station to coupe
} 
TABLE 2

Plant species sampled for insects on each harvesting unit

Plant species Coupe

SW 48 SW $51 \quad$ TO 54 MC 33 EL 10

Acacia dealbata* ${ }^{*}$ Link

Acacia genistifolia Link

Acacia mearnsii De Wild.

Acacia melanoxylon $\mathrm{R} . \mathrm{Br}$.

Acacia myrtifolia (Smith)Willd.

Acacia terminalisn(Salisb.)Macbr.

Acacia verniciflua A.Cunn.

Acacia verticillata (L'HÈrit.)Willd.

Allocasuarina littoralis (Salisb.)L.Johnson

Amperea xiphoclada (Sieb. ex Sprengel) Druce

Aotus ericoides (Vent.) G.Don

Banksia marginata Cav.

Bossiaea cinerea R:Br.

Bursaria spinosa Cav.

Cassinia aculeata (Labill.)R.Br.

Comesperma volubile Labill.

Cyathodes glauca Labill.

Daviesia ulicifolia Andrews

Dianella tasmanica Hook.f.

Epacris impressa Labill.

Eucalyptus amygdalina Labill.

Eucalyptus dalrympleana Maiden

Eucalyptus delegatensis R.Baker

Eucalyptus globulus Labill.

Eucalyptus obliqua L'HÈrit.

Eucalyptus ovata Labill.

Eucalyptus pulchella Desf.

Eucalyptus sieberi L.Johnson

Eucalyptus tenuiramis Miq.

Eucalyptus viminalis Labill.

Exocarpos cupressiformis Labill.

Gahnia grandis (Labill.)S.T.Blake

Goodenia ovata Smith

Lepidosperma elatius Labill.

Leptospermum scoparium Forst. \& Forst.f.

Leucopogon ericoides (Smith) R.Br.

Lomandra longifolia Labill.

Lomatia tinctoria (Labill.) R.Br.

Monotoca glauca (Labill.) Druce

Olearia lirata (Sims.) Hutch.

Olearia viscosa (Labill.) Benth.

Oxylobium ellipticum (Labill.) R.Br.

Polystichum proliferum (R.Br.) C.Presl

Pomaderris apetala Labill.

Pteridium esculentum (Forst.f.) Cockayne

Pultenaea daphnoides J. Wendl.

Pultenaea gunnii Benth.

Pultenaea juniperina Labill.

Senecio minimus Poiret

Tetratheca labillardierei J.Thompson

* Bold type indicates plant species which were confirmed hosts for insects collected in the study. 
The understorey was characterised by short (up to $4 \mathrm{~m}$ ), often prickly shrubs with a significant grassy/sedgy component in some areas. Seventy-two species of dicotyledons, 24 monocotyledons and five fern species were recorded across all the study areas before logging commenced. The most common plant families and genera present were Fabaceae (Pultenaea), Mimosaceae (Acacia), Proteaceae (Banksia, Lomatia), Asteraceae (Olearia, Senecio), Epacridaceae (Epacris), Xanthorrhoeaceae (Lomandra) and Poaceae (Poa, Danthonia). A detailed analysis of the botany from the study areas is in preparation.

Logging and regeneration burning removed most of the overstorey and severely damaged many of the understorey plants. The young forests established following logging have very high stockings of eucalypts (1000-5000 stems $\mathrm{ha}^{-1}$ ) compared with the forests present before logging (Elliott et al. 1991). The species composition of the postlogging vegetation at all the study sites is similar to that which existed prior to logging although there has been an overall increase in species richness, and the structure and relative dominance of the various species has changed ( $M$. Neyland, unpublished data).

\section{Insect Sampling}

Insect sampling was conducted on all plots at one-month intervals prior to the logging and regeneration treatment and at approximately three-month intervals (mid-spring, summer, autumn and winter) following treatment. The number of sampling occasions over the nine years ranged from 41-45 for plots within the coupes EL 10, MC 33 and TO 54. However, because of coupe rescheduling and other operational reasons, plots within coupes SW 48 and SW 51 were sampled only 16 and 26 times respectively. Insects occurring on vegetation greater than $30 \mathrm{~cm}$ in height were sampled using sweeping, beating and hand-collecting techniques. On each sampling occasion, three to five individuals of each plant species on each plot were swept with a standard $30 \mathrm{~cm}$-diameter collecting net and the captured insects were stored in $70 \%$ ethyl alcohol or pinned for later identification. Insects were also sampled by holding a $1 \mathrm{~m}^{2}$ canvas beating tray beneath the foliage of the plant and collecting (by hand or with an aspirator) all insects dislodged by beating branches with five blows from a stick. Where sufficient plants of each species were available, beating was conducted on different individual plants to those sampled by sweeping; otherwise, the same plants were sampled by both methods. Prior to logging in the mature forests, only the lower foliage of mature trees and small trees beneath the canopy could be sampled, whereas in the newly regenerated forests all sections of the tree canopy could be accessed. The plant species sampled are listed in table 2 . On each sampling occasion, all insect species collected from each plant species were recorded and insect/host plant associations noted where feeding was observed.

Light trapping was conducted on suitable nights at all plots throughout the sampling period. Initially, the light traps used were constructed from galvanised sheet metal and consisted of a rectangular killing box supporting a 15watt UV fluorescent tube covered with a perspex roof. In the second year following logging, these traps were replaced by cylindrical plastic light traps supporting a vertically mounted, 15-watt fluorescent UV tube surrounded by three perspex vanes. Light traps were charged with dichlorvos in the form of Shell Pest Strips ${ }^{\circledR}$.

\section{Insect Identification}

Insects were initially identified to family level and sent to taxonomic specialists for further identification. For families where taxonomic assistance was unavailable, lists of coded putative species were assembled by the authors. An extensive reference collection of named and coded insect species was maintained to assist with identifications throughout the study.

\section{Data Set}

Information collected from sampling the plots consisted of occurrences of insect species on plant species for each plot and sampling date, noting any feeding activity. No abundance data were collected. Data for the 522 sampling occasions were stored in DECODA (Minchin 1991), a data-handling package which allows basic statistics on species numbers and composition of the fauna to be calculated easily. It also presents the data in a format suitable for the input files used by several other programs which undertake multivariate analyses.

\section{Nomenclature}

Species nomenclature follows Naumann (1993) for insects and Buchanan (1999) for plants.

\section{RESULTS}

\section{Composition of the Insect Fauna}

In all, 1164 species (named and putative) representing 17 orders and 157 families were collected from plants and in light traps on the plots during the study. The level to which these species could be identified varied greatly depending on taxonomic problems in the groups and the availability of taxonomic expertise. One-third (388) of these species were identified at least to genus level. The total insect fauna collected during the study is listed by order and family in appendix 1 .

The bulk of the insect fauna was contained in the orders Coleoptera (322 species), Hymenoptera (294 species), Hemiptera (209 species), Lepidoptera (169 species) and Diptera (112 species) (table 3). Over half the species of Coleoptera collected were leaf-eating beetles (Chrysomelidae) and stem-boring and leaf-feeding weevils (Curculionidae). The most species-rich families among the sap-feeders (Hemiptera) were the Psyllidae (79 species) and the Cicadellidae (40 species). Most of the Hymenoptera collected were parasitoids and gall formers in the superfamily Chalcidoidea (120 species) and the families Braconidae (50 species) and Ichneumonidae (28 species). Twenty-nine species of ants (Formicidae) were recorded during the study. Larvae of Lepidoptera were common defoliators of a wide range of host plants, although most species recorded were adult moths caught in light traps (table 4). Geometridae 
TABLE 3

Summary of insect fauna by taxonomic group

\begin{tabular}{|c|c|c|c|c|c|}
\hline Order & $\begin{array}{l}\text { Number of } \\
\text { families }\end{array}$ & $\begin{array}{c}\text { Number of } \\
\text { named species }\end{array}$ & $\begin{array}{c}\text { Number of } \\
\text { putative species }\end{array}$ & $\begin{array}{l}\text { Total number } \\
\text { of species }\end{array}$ & $\begin{array}{l}\text { Percentage of } \\
\text { total insect fauna }\end{array}$ \\
\hline Coleoptera & 29 & 86 & 236 & 322 & 28 \\
\hline Hymenoptera & 22 & 31 & 263 & 294 & 25 \\
\hline Hemiptera & 25 & 113 & 96 & 209 & 18 \\
\hline Lepidoptera & 25 & 128 & 41 & 169 & 14 \\
\hline Diptera & 31 & - & 112 & 112 & 10 \\
\hline Orthoptera & 2 & 6 & 4 & 10 & $<1$ \\
\hline Collembola & 8 & 6 & 3 & 9 & $<1$ \\
\hline Thysanoptera & 1 & - & 9 & 9 & $<1$ \\
\hline Psocoptera & 4 & 6 & 1 & 7 & $<1$ \\
\hline Blattodea & 1 & 1 & 5 & 6 & $<1$ \\
\hline Neuroptera & 3 & 5 & & 5 & $<1$ \\
\hline Plecoptera & 2 & 2 & 4 & 6 & $<1$ \\
\hline Odonata & 2 & 1 & 1 & 2 & $<1$ \\
\hline Trichoptera & 1 & - & 1 & 1 & $<1$ \\
\hline Mecoptera & 1 & 1 & - & 1 & $<1$ \\
\hline Mantodea & 1 & 1 & - & 1 & $<1$ \\
\hline Dermaptera & 1 & - & 1 & 1 & $<1$ \\
\hline TOTAL & 159 & 387 & 777 & 1164 & \\
\hline
\end{tabular}

TABLE 4

Number of species in families of Lepidoptera recorded from light trap collections

\begin{tabular}{lc}
\hline Family & Number of species \\
\hline Anthelidae & 7 \\
Arctiidae & 8 \\
Cossidae & 1 \\
Cosmopterygidae & 1 \\
Gelechiidae & 1 \\
Geometridae & 59 \\
Gracillariidae & 2 \\
Heliozelidae & 2 \\
Hepialidae & 7 \\
Lasiocampidae & 5 \\
Limacodidae & 1 \\
Lycaenidae & 2 \\
Lymantriidae & 2 \\
Noctuidae & 24 \\
Notodontidae & 3 \\
Nymphalidae & 7 \\
Oecophoridae & 8 \\
Pieridae & 1 \\
Psychidae & 3 \\
Pyralidae & 4 \\
Saturniidae & 1 \\
Sphingidae & 1 \\
Thaumetopoeidae & 2 \\
Tortricidae & 58 \\
Zygaenidae & 1 \\
TOTAL &
\end{tabular}


(66 species) and Noctuidae (24 species) were the dominant families of Lepidoptera.

The 388 species named to at least genus level by specialist taxonomists included 21 named species which are not included in the list of Tasmanian insect fauna (Semmens et al. 1992) and a further 90 species yet to be formally described (see appendix 1). Over half of these 'new' species (63) were psyllids (Hemiptera: Psyllidae) with the remainder scattered among the other orders. Many more insects in the collection of 776 unidentified putative species are expected to be previously unrecorded in Tasmania.

The broad-striped ghost moth, Fraus latistria Walker (Lepidoptera: Hepialidae), one of the named species collected, is listed in Tasmania's Threatened Fauna Manual (Bryant \& Jackson 1999) and has a status of 'rare' as defined by Tasmania's Threatened Species Protection Act 1995. This species was collected by light-trap sampling on 21 March 1978 in coupe SW 51, a new locality record for the species.

The composition of the insect fauna showed only minor variation across the study area. A variety of multivariate analyses were undertaken on the data beginning with detrended correspondence analysis using the program DECORANA (Hill 1979a). Because of limitations on the size of data sets with microcomputers, the more robust procedure for indirect gradient analysis, multidimensional scaling (see Minchin 1991), was used only on subsets of the data. It was performed with the program MDS (Minchin 1991), using global non-metric multidimensional scaling followed by hybrid non-metric multidimensional scaling as recommended by Kantvilas \& Minchin (1989). The classificatory program TWINSPAN (Hill 1979b) was also used to examine the data. None of the analyses showed any separation of insect assemblages according to coupe of origin. The data do not appear to be well-suited to the techniques because of the low number of species in many samples and the high number of species recorded only a few times (over three-quarters of the species were collected on less than five sampling occasions). Many analyses were re-run with rare species and sample outliers were removed progressively but little improvement was achieved.

\section{Species Richness}

The numbers of species collected from each of the harvesting coupes were generally similar taking into account differences in altitude, rainfall, geology and vegetation. Species numbers collected per coupe over the sampling period ranged from 464 to 556 species, with the exception of SW 48 where the numbers were much lower (286 species).

Differences in species richness were more marked at the plot level. The total number of species per plot ranged from 180 to 308 except for SW 48. Again the total number of species was lower than in the other coupes, ranging from 118 to 140 species over the three plots. The lower figures for SW 48 at both the coupe and plot level are attributed, at least in part, to the smaller number of sampling occasions possible due to operational constraints. In all coupes and in all plots species numbers varied greatly on individual sampling occasions. Typical figures ranged from 5-20 species, the highest number on any single sampling occasion being 42 and the lowest being zero.
As expected, species richness varied markedly according to the season of collection when seasons were arbitrarily defined as follows: September to November (spring), December to February (summer), March to May (autumn) and June to August (winter). Analysis of the total collection on this basis showed that the numbers per collection (mean \pm s.e.) for spring, summer, autumn and winter were 12.9 $\pm 0.7(n=131), 13.7 \pm 0.7(n=157), 10.5 \pm 0.6(n=129)$ and $5.5 \pm 0.4(\mathrm{n}=101)$ respectively. Seasonal occurrences of many of the main plant-feeding insects, particularly defoliators, were common to most plots. For example, in early spring, young eucalypt leaves were often eaten by the adults of small melolonthine scarab beetles, mainly Heteronyx spp. Several species of Lepidoptera larvae were collected during winter and spring and larvae of the fireblight beetle, Acacicola orphana, were common on Acacia dealbata and $A$. mearnsii in the same period where these tree species were present on the plots. In late spring, summer and autumn, leaf beetle (Chrysomelidae) eggs, larvae and adults were present on several species of eucalypts together with their common predators: adult soldier beetles (Chauliognathus spp.) and larval and adult ladybird beetles (Coccinellidae).

\section{Insect/Host Plant Associations}

A total of 132 insects named to genus or species level were recorded actually feeding on 22 of the 50 plant species sampled on the plots during the survey. An additional 39 insect species had known hosts (Bashford 1990) on the plots where they were collected but were not observed actually feeding at the time of collection. Most of these insects were recorded feeding on eucalypts (127 insect species) and acacias (38 species) with lower numbers recorded from Banksia (5 species), Allocasuarina (4), Exocarpos (4), Leptospermum (3), Goodenia (2) and Pultenaea (1). Twentyfive insect families contained eucalypt feeders, with most species recorded from Chrysomelidae (leaf beetles) and Psyllidae (lerps). Four of the six eucalypt-feeding sawflies (Pergidae) found in Tasmania (Elliott \& Bashford 1996) were collected on the plots (appendix 1).

A listing of these 171 species by their host plants is shown in appendix 2. Eighty-five of these species were found feeding on only one host plant species during the study but host specificity is not well documented and cannot be assumed. The most polyphagous and commonly collected species were several well-known pests of eucalypts and acacias: eucalypt weevil Gonipterus scutellatus (Gyllenhal) (ten eucalypt hosts); gumleaf skeletonizer Uraba lugens Walker (nine eucalypt hosts); gumtree bug Amorbus obscuricornis (Westwood) and the chrysomelid beetle Paropsis porosa Erichson (each with eight eucalypt hosts); gumtree scale Eriococcus coriaceous Maskell, the machaerotid Chaetophyes compacta (Walker), the chrysomelid beetles Trachymela rugosa (Chapuis) and Chrysophtharta nobilitata (Erichson), and the psyllid Glycaspis sp. (each with seven eucalypt hosts).

Host plants in rank order supporting the richest insect fauna were Eucalyptus amygdalina (74 species), E. obliqua (64), E. viminalis (46), Acacia dealbata (35), E. dalrympleana (33), E. sieberi (31), E.delegatensis (30), E. pulchella (24) and E. globulus (19). 


\section{DISCUSSION}

The 1164 insect species collected during this study, together with the host plant records for 171 insect species, represent a significant increase in our knowledge of the insect fauna in Tasmania's dry eucalypt forests. Among the 388 species identified at least to genus level, the collection of 21 named species not previously listed in the Tasmanian insect fauna (Semmens et al. 1992) and a further 90 yet to be described but apparently new species emphasise the low level of knowledge about the insect fauna in these forests. The high proportion of Psyllidae in this previously unlisted collection is in part due to the availability of specialist taxonomic expertise for that particular group. Further taxonomic investigation of other groups will undoubtedly result in many more previously unlisted species. The total number of species (identified and putative) collected in the study represents nearly $8 \%$ of the estimated 15000 non-marine insect species in Tasmania (Greenslade 1985).

Although a large number of species was collected during the study reported here, total species numbers and composition of collections were obviously influenced by the extent and frequency of sampling at the study sites, climatic conditions at the time of sampling, stages of plant development present (e.g. flowering, new shoot extension) and many other factors. For much of the study, sampling of each plot occurred at quarterly intervals and was conducted regardless of weather conditions. Therefore, some collections may be biased towards species which are relatively sedentary feeders on their host plants and so less affected by rain, wind and cool conditions.

Levels of endemism for the insects collected are not known although Greenslade (1985) reported that the highest endemicity in the Tasmanian insect fauna occurred in the rainforest and alpine environments, and dry forests probably had low to medium levels, perhaps in the range $20-70 \%$, varying widely between insect groups. For example, endemicity of $30 \%$ was reported for Coccinellidae (one of the most species-rich groups collected in our study) in eucalypt forests (Greenslade 1985).

The collection of the broad-striped ghost moth, Fraus latistria, at the unlogged SW 51 coupe in eastern Tasmania extends the distribution of this rare insect. This species has been previously recorded only from the Hobart and Launceston areas and Scotts Peak Dam in southwestern Tasmania (Bryant \& Jackson 1999).

Although no similar studies have been previously reported from these forests in Tasmania, other studies in different forest types or in different habitats in dry eucalypt forests on mainland Australia are available for comparison of the size and composition of elements of the insect fauna. In a study by Neumann (1978) using systematic malaise trap sampling of mature dry peppermint-gum eucalypt forest (E. dives $-E$. radiata $-E$. macrorhyncha) in Victoria, the most abundant (in terms of number of specimens collected) were (in rank order): Diptera, Hymenoptera, Coleoptera, Hemiptera and Lepidoptera. These orders were also the most species-rich orders of insects recorded in our Tasmanian study although Diptera ranked lowest rather than highest as in the Victorian study.

In a study of beetle communities using periodic malaise trapping in the same forests in Victoria, Neumann (1979) recorded 199 species of Coleoptera (beetles) from 47 families. The most frequently collected families in this study were Chrysomelidae, Staphylinidae, Alleculidae,
Coccinellidae, Scarabaeidae, Mordellidae, Curculionidae, Melyridae and Anisotomidae. In two studies of the species composition of the litter-inhabiting Coleoptera in Victorian dry eucalypt forests (E. obliqua-E.radiata-E. rubida), 109 species from 30 families (Neumann et al. 1995) and 105 species from 31 families (Collett \& Neumann 1995) were collected. Undescribed species comprised $67 \%$ and $72 \%$ respectively of the collections from these studies. In our Tasmanian study, 322 named and putative species of Coleoptera from 29 families were collected on vegetation and the proportion of undescribed species (74\%) was similar to that recorded for the Victorian fauna.

Ohmart et al. (1983) in a study of leaf-chewing insects in subalpine $E$. delegatensis $-E$. dives $-E$. pauciflora forest in the Australian Capital Territory (ACT), reported that the major taxa (expressed as numbers of insects per kilogram of foliage dry weight) were micro-Lepidoptera, Geometridae, Chrysomelidae and Curculionidae; Cercopidae, Cicadellidae and Fulgoroidea were the major families of sap feeders. Similarly, in the Tasmanian study, Chrysomelidae and Curculionidae were the most species-rich families of Coleoptera, and Geometridae was the most species-rich family of Lepidoptera even though the eucalypt forest types sampled were quite different from the subalpine forests of the ACT. Leafhoppers (Cicadellidae) and psyllids (Psyllidae) were the predominant families of sap-feeders collected in eastern Tasmania, but psyllids were rarely collected in the subalpine forests (Ohmart et al. 1983). Although there are some obvious similarities between the foliage-dwelling insect fauna of Tasmanian dry eucalypt forests and some mainland forests, definitive comparisons are difficult because of the different measures used (species richness, number of specimens, insects per weight of foliage) and habitats sampled.

As stated above, Geometridae was the most species-rich family of Lepidoptera recorded in this study. The larvae of many species are common defoliators in these dry forests, particularly of eucalypts and acacias. Nine of the geometrid species collected were also recorded by McQuillan et al. (1998) in dry eucalypt forest at Old Chum Dam in northeastern Tasmania.

In a recent invertebrate survey of rainforest in Tasmania, 618 insect species from 22 orders were collected by sweeping and beating vegetation (the sampling technique used in the present study) and the most frequently collected families were Collembola and Diptera, with Coleoptera, Hymenoptera, Psocoptera and Lepidoptera reasonably abundant. Again, undescribed species made up some $75 \%$ of the total. Overall, using several sampling methods across many rainforest habitats, Coleoptera was the most diverse group containing 367 species from 44 families (Coy et al. 1993), a similar result to that obtained from our sampling of Tasmanian dry eucalypt forests.

The large number of insects feeding on eucalypts and acacias in the list of insect/host plant associations is not unexpected considering the domination of eucalypts, and to a lesser extent acacias, in these forests. In particular, the high number of eucalypt stems per hectare in the young regenerating forests (Elliott et al. 1991) in which the postlogging sampling was conducted, their fast growth rate and larger tree size compared to other plants would contribute to the high capture rate among eucalypt feeders compared to the general fauna. In addition to the dominance of eucalypts and acacias at the study sites, many of the insects feeding on these host genera are widely distributed and 
polyphagous. They were therefore frequently collected on all plots, together with their predators and parasites. These are important contributing factors to the lack of separation of insect assemblages according to coupe of origin.

\section{ACKNOWLEDGEMENTS}

We gratefully acknowledge the encouragement and assistance of Keith Taylor (CSIRO) in establishing this study. The following taxonomists provided species identifications in their respective groups: Drs E. Zimmerman (Curculionidae), R. Taylor (Formicidae), I. Common (Lepidoptera), J. Lawrence (Coleoptera), T. New (Neuroptera, Psocoptera), J. Ireson (Collembola), P. McQuillan (Scarabaeidae, Acrididae), M. Fletcher (Cicadellidae), D. de Little (Chrysomelidae), and Mr L. Hill (Noctuidae).

\section{REFERENCES}

BASHFORD, R., 1990: Tasmanian Forest Insects and their Host Plants. Forestry Commission, Tasmania.

BASHFORD, R., 1993: Macrolepidoptera of the Scamander Forest Reserve in north east Tasmania. Australian Entomologist 20: 145-151.

Bryant, S. \& JACKSON, J., 1999: Tasmania's Threatened Fauna Manual: what, where, and how to protect Tasmania's threatened animals. Threatened Species Unit, Parks and Wildlife Service.

Buchanan, A.M. (Ed.), 1999: A Census of the Vascular Plants of Tasmania and Index to 'The Students Flora of Tasmania'. Tasmanian Herbarium Occassional Publication 6. Tasmanian Herbarium, Hobart.

Collett, N.G. \& Neumann, F.G., 1995: Effects of two spring prescribed fires on epigeal Coleoptera in dry sclerophyll eucalypt forests in Victoria, Australia. Forest Ecology and Management 76: 69-85.

Coy, R., Greenslade P. \& Rounsevell, D., 1993: A Survey of Invertebrates in Tasmanian Rainforest. Tasmanian National Rainforest Conservation Program Technical Report 9. Parks and Wildlife Service, Tasmania, and Department of the Arts, Sport, the Environment and Territories, Canberra.

ElliotT, H.J. \& BASHFord, R., 1996: Notes on the biology and behaviour of eucalypt-defoliating sawflies (Hymenoptera: Pergidae) in Tasmania. Tasforests 7: 27-36.

Elliott, H.J., Bashford, R. \& GoOdwin, A., 1991: Species composition, stocking and growth of dry eucalypt forest before and after logging in eastern Tasmania. Tasforests 3: 76-84.

ElliotT, H.J. \& DE LitTle, D.W., 1984: Insect Pests of Trees and Timber in Tasmania. Forestry Commission, Hobart.

Elliott, H.J., Ohmart, C.P. \& Wylie, F.R., 1998: Insect Pests of Australian Forests - Ecology and Management. Inkata Press, Melbourne.
Felton, K.C. \& Cunningham, T.M., 1971: Woodchip exports and pulpwood forestry in eastern Tasmania. Proceedings of the conference of the Institute of Foresters of Australia, Thredbo, NSW.

Greenslade, P., 1985: Conservation priorities in Tasmanian non-marine invertebrates. Unpublished report. Tasmanian National Parks and Wildlife Service.

Hickman, J.L. \& Hill, L., 1978: Terrestrial Invertebrates. Lower Gordon Scientific Study. Unpublished Report, HydroElectric Commission, Hobart.

Hill, M.O., 1979a: DECORANA. A FORTRAN Program for Detrended Correspondence Analysis and Reciprocal Averaging. Ecology and Systematics, Cornell University, Ithaca, New York.

HILl, M.O., 1979b: TWINSPAN. A FORTRAN Program for arranging Multivariate Data in an Ordererd Two-Way Table by Classification of the Individuals and Attributes. Ecology and Systematics, Cornell University, Ithaca, New York.

Kantvilas, G. \& Minchin, P.R., 1989: An analysis of epiphytic lichen communities in Tasmanian cool temperate rainforest. Vegetatio 84: 99-112.

McQuillan, P.B., Taylor, R.J., Brereton, R.N.\& Cale, P.G., 1998: Seasonal patterns of activity in Geometrid moths (Lepidoptera: geometridae) from a lowland and highland eucalypt forest in Tasmania. Australian Journal of Entomology 37: 228-237.

Minchin, P.R., 1991: DECODA. Database for Ecological Data. Notes on performing Multidimensional Scaling with $D E C O D A$ and $M D S$. Australian National University, Canberra.

NAUMANn, I.D., 1993: CSIRO Handbook of Australian Insect Names. 6th edition. CSIRO, Australia.

Neumann, F.G., 1978: Insect populations in eucalypt and pine forests in north-eastern Victoria. Australian Forest Research 8: $13-24$.

Neumann, F.G., 1979: Beetle communities in eucalypt and pine forests in north-eastern Victoria. Australian Forest Research 9: $277-295$.

Neumann, F.G., Collett, N.G. \& Tolhurst, K.G., 1995: Coleoptera in litter of dry sclerophyll eucalypt forest and the effects of low intensity prescribed fire on their activity and composition in west-central Victoria. Australian Forestry 58: 83-98.

Ohmart, C.P., Stewart, L.G. \& Thomas, J.R., 1983: Phytophagous insect communities in the canopies of three Eucalyptus forest types in south-eastern Australia. Australian Journal of Ecology 8: 395-403.

Semmens, T.D., McQullan, P.B. \& Hayhurst, G., 1992: Catalogue of the Insects of Tasmania. Department of Primary Industry, Hobart.

Senate Standing Committee on Science and the Environment, 1977: Woodchips and the Environment. Report from the Senate Standing Committee on Science and the Environment. Australian Government Publishing Service, Canberra.

(accepted 29 July 2002) 
APPENDIX 1

\section{Total insect fauna collected from study plots}

Order/Family/Species

Blattodea

Blattidae

Platyzosteria melanaria (Erichson) 5 unidentified species

Coleoptera

Alleculidae

$$
2 \text { unidentified species }
$$

Anobiidae

5 unidentified species

Bostrychidae

Xylion collaris (Erichson)

Buprestidae

Cisseis acudata (Kirby)

Castiarina wilsoni (Saunders)

Ethon affine (Laporte \& Glory)

Germarica lilliputana (Thomson)

Melobasis innocua (Thomson)

Melobasis sparsa (Levy)

Nascioides parryi (Hope)

Byrrhidae

1 unidentified species

Cantharidae

Chauliognathus lugubris (Fabricius)

Chauliognathus nobilitatus (Erichson)

14 unidentified species

Carabidae

5 unidentified species

Cerambycidae

Ancita marginicollis (Boisduval)

Bethelium signiferum (Newman)

Coptocercus rubripes (Boisduval)

Pytheus erosus (Macleay)

Tessaromma sericans (Erichson)

Tessaromma undatum Newman

Toxeutes arcuatus (Fabricius)

Zoedia divisa (Pascoe)

2 unidentified species

Chrysomelidae

Acacicola hamadryas Stal

Acacicola orphana (Erichson)

Altica pagana Blackburn

Cadmus australis Boisduval

Cadmus crincicollis Boisduval *

Cadmus sp. $4^{*}$

Cadmus strigillatus Chapuis

Chrysophtharta aurea Blackburn

Chrysophtharta bimaculata (Olivier)

Chrysophtharta crucata (Boisduval) *

Chrysophtharta decolorata (Chapuis)

Chrysophtharta nobilitata (Erichson)

Chrysophtharta philomela Blackburn

Chrysophtharta sp. $\mathrm{a}^{*}$

Chrysophtharta sp. $\mathrm{b}^{\#}$

Chrysophtharta sp.c. $\mathrm{c}^{\#}$

Chrysophtharta sp. $\mathrm{f}^{*}$

Chrysophtharta sp.h"

Paropsides umbrosa Chapuis

Paropsis aegrota var. elliotti Selman*

Paropsis deboeri Selman

Paropsis dilatata Erichson

Paropsis porosa Erichson

Paropsis sp. $\mathrm{a}^{\#}$

Paropsis tasmanica Baly

Paropsisterna nucea (Erichson)

Platycolaspis australis Jacoby

Trachymela papulosa (Chapuis)*

Trachymela rugosa (Chapuis)

58 unidentified species
Cleridae

Blackburniella hilaris (Westwood)

Eleale sp.

4 unidentified species

Coccinellidae

Cleobora mellyi Mulsant

Coccinella repanda Thunberg*

21 unidentified species

Colyiidae

3 unidentified species

Cucujoidea

4 unidentified species

Curculionidae

Acalonoma pusilla Blackburn*

Autetobius sp."

Belus bidentatus (Donovan)

Belus bimaculatus Pascoe

Euthyphasis acutd Pascoe*

Gonipterus gibberus Boisduval

Gonipterus lepidotus Gyllenhal

Gonipterus scutellatus (Gyllenhal)

Gonipterus sp.

Haplonyx sp.

Merimnetes sp

Pachyura australis Hope

Myllorhinus multidentatus (Chevrolet)

Myllorhinus bicaudatus (Boisduval)

Rhadinosomus lacordairei Pascoe

Scotasmus sp.

Syarbis alcyone Lea

65 unidentified species

Elateridae

Agrypnus pictipennis (Candeze)

11 unidentified species

Lathridiidae

2 unidentified species

Lucanidae

Syndesus cornutus Fabricius

Lycidae

Metriorrhynchus sp.a

Metriorrhynchus sp.b

Melandryidae

4 unidentified species

Melyridae

5 unidentified species

Mordellidae

5 unidentified species

Nitidulidae

7 unidentified species

Oedemeridae

Dohrnia miranda Newman

1 unidentified species

Phalacridae

1 unidentified species

Ptinidae

1 unidentified species

Scarabaeidae

Diphucephala colaspidoides (Gyllenhal)

Heteronyx crinitus Blackburn

Heteronyx sp.a

Heteronyx sp.b

Heteronyx sp.c

Liparetus atratus Burmeister

Liparetus convexus Boisduval

Phyllotocus erythropterus Blanchard

Xylonychus piliger Blanchard

4 unidentified species

Scraptiidae

Scraptia sp.

1 unidentified species 


\section{APPENDIX 1 cont}

\author{
Staphylinidae \\ 8 unidentified species \\ Tenebrionidae \\ Lepispilus sulcicollis (Boisduval) \\ 2 unidentified species
}

Collembola

Hypogastruridae

Hypogastrura purpurescens (Lubbock)

Entomobryidae

Australotomurus sp.

Lepidocyrtoides sp."

Sminthuridae

Rastriopes $\mathrm{sp}^{\#}$.

Polykatianna sp."

Tomoceridae

$$
\text { Lepidophorella sp." }
$$

Paronellidae

3 unidentified species

Dermaptera

Forficulidae

1 unidentified species

Diptera

Agromyzidae

2 unidentified species

Anisopodidae

1 unidentifed species

Asilidae

6 unidentifed species

Bibionidae

3 unidentifed species

Bombyliidae

1 unidentified species

Calliphoridae

3 unidentifed species

Cecidomyiidae

3 unidentified species

Ceratopogonidae

3 unidentifed species

Chironomidae

14 unidentified species

Chloropidae

7 unidentified species

Clusiidae

1 unidentified species

Culicidae

1 unidentified species

Dolichopodidae

6 unidentified species

Empididae

8 unidentified species

Fergusoninidae

1 unidentified species

Heliomyzidae

2 unidentified species

Lauxaniidae

3 unidentified species

Muscidae

1 unidentified species

Mycetophilidae

5 unidentified species

Perissommatidae

1 unidentified species

Phoridae

4 unidentified species

Platystomatidae

2 unidentified species

Rhagionidae

3 unidentified species
Scatopsidae

1 unidentified species

Scenopinidae

1 unidentified species

Sciaridae

8 unidentified species

Stratiomyidae

3 unidentified species

Syrphidae

4 unidentified species

Tabanidae

3 unidentified species

Tachinidae

5 unidentified species

Tipulidae

6 unidentifed species

Hemiptera

Acanthosomatidae Anischys sp.

Alydidae

1 unidentified species

Aphididae

4 unidentified species

Cicadellidae

Alocephalus ianthe (Kirkaldy)*

Austrolopa brunensis Evans

Batracomorphus augustatus (Evans)*

Batracomorphus elegans (Evans)

Batracomorphus ?elegans

Batracomorphus sp."

Euleimonios sp.nov."

Haplodelphax iuncicola (Kirkaldy)*

Ipoella sp. ${ }^{\#}$

Kahaono sp.

Neotartessus flavipes (Spanberg)

Paralimnus smithtoniensis Evans

Rosapaella evansi Webb

Rosopaella cuprea (Walker)

Rosopaella sp.

Rubria sp.

Rubria sp a.

Rubria sp b.

Stenocotis depressa (Walker)

Tenuitartessus blundellensis (Evans)

Trocnada sp."

Vulturnus sp."

Zygina evansi (Ross)

Zygina zealandica (Myers)

15 unidentified species

Cicadidae

Cicadetta torrida (Erichson)

Cixiidae

4 unidentified species

Coccidae

7 unidentified species

Coreidae

Amorbus obscuricornis (Westwood)

Gelonus tasmanicus (Le Guillou)

Eniocephalidae

1 unidentified species

Eriococcidae

Eriococcus coriaceus Maskell

Eurymelidae

Eurymeloides bicincta (Erichson)

3 unidentified species

Flatidae

Siphanta hebes (Walker)

Lygaeidae

Euander lacertosus (Erichson)

8 unidentified species 


\section{APPENDIX 1 cont.}

Machaerotidae

Chaetophyes compacta (Walker)

3 unidentified species

Membracidae

Naunus tasmaniae (Fairmaire) *

4 unidentified species

Miridae

19 unidentified species

Nabidae

Nabis sp.

Pentatomidae

Cermatulus nasalis (Westwood)

Dictyotus caenosus (Westwood)

16 unidentified species

Piesmidae

1 unidentified species

Pseudococcidae

5 unidentified species

Psyllidae

Aacanthocnema sp.

Aacanthocnema? dobsoni $(\mathrm{Fr} .)^{\star}$

Acizzia ?sp."

Acizzia sp."

Acizzia sp.a ${ }^{\#}$

Acizzia sp.b

Acizzia sp.c ${ }^{\#}$

Acizzia sp.d $\mathrm{d}^{*}$

Acizzia sp.e ${ }^{\#}$

Acizzia sp.f*

Acizzia sp.g*

Acizzia sp.h"

Acizzia sp.i. ${ }^{*}$

Acizzia sp.j ${ }^{\#}$

Acizzia sp.k ${ }^{\#}$

Acizzia sp. . $^{\#}$

Anoeconeossa copidiformis Taylor

Australopsylla?(nr.)sp.a ${ }^{\#}$

Australopsylla?marmorata

Australopsylla marmorata (Froggatt)

Australopsylla sp. $\mathrm{a}^{\#}$

Australopsylla sp. $\mathrm{b}^{\#}$

Australopsylla sp.c ${ }^{\#}$

Australopsylla sp.d ${ }^{\#}$

Cardiaspina? sp."

Cardiaspina ?spinifera (Froggatt)

Creiis ? sp. ${ }^{\#}$

Creiissp. "tas"\#

Creiis sp. $\mathrm{a}^{\#}$

Ctenarytaina b1 ${ }^{\#}$

Ctenarytaina $\mathrm{I}^{\#}$

Ctenarytaina $\mathrm{k}^{\#}$

Ctenarytaina sp.

Ctenarytana a3"

Ctenarytana $\mathrm{b}^{\#}$

Ctenarytana $\mathrm{c}^{*}$

Ctenarytana $\mathrm{d}^{*}$

Ctenarytana $\mathrm{d} 2$

Ctenarytana eucalypti (Maskell)

Glycaspis dobsoni Moore*

Glycaspis dreptodria Moore

Glycaspis planitecta Moore

Glycaspis sp."

Hyalinaspis ?rubra

Hyalinaspis rubra (Froggatt)

Hyalinaspis sp."

Phellopsylla $\mathrm{a}^{\#}$

Phellopsylla $\mathrm{b}$

Phellopsylla $\mathrm{c}^{\#}$

Phellopsylla $\mathrm{d}^{*}$

Phellopsylla $\mathrm{e}^{\#}$

Phellopsylla $\mathrm{n}^{\#}$
Phellopsylla $\mathrm{n} 2^{\#}$

Phellopsylla sp."

Platylobria maddeni Taylor

Schedotrioza ?\#

Schedotrioza $\mathrm{a}^{\#}$

Schedotrioza $\mathrm{b}^{\#}$

Schedotrioza $\mathrm{c}^{\#}$

Schedotrioza $\mathrm{d}^{\#}$

Schedotrioza sp."

Schedotrioza sp. $1^{\#}$

Schedotrioza sp. $2^{\#}$

Spondyliaspis? gen. et sp. nov."

Trioza? $\mathrm{sp}^{\#}$

Trioza $\mathrm{b}^{\#}$

Trioza ? $\mathrm{c}^{\#}$

Trioza $\mathrm{a}^{\#}$

Trioza $\mathrm{b}^{\#}$

Trioza $\mathrm{d}^{\#}$

Trioza $\mathrm{e}^{\#}$

Trioza $n$ r.a ${ }^{\#}$

Trioza $n r . \mathrm{b}^{\#}$

Reduviidae

5 unidentified species

Scutelleridae

Scutiphora pedicellata (Kirby)

Thaumastocoridae

Baclozygum depressum Bergroth

Tingidae

Epimixia sp.

Hymenoptera

Apidae

Apis mellifera Linnaeus

Bethylidae

8 unidentified species

Braconidae

Doryctes sp.

Syngaster sp. ${ }^{*}$

Trichiobelcon rufoniger (Turner)

47 unidentified species

Chalcidoidea

120 unidentified species

Chrysididae

3 unidentified species

Cleptidae

3 unidentified species

Colletidae

5 unidentified species

Cynipidae

6 unidentifed species

Eumenidae

2 unidentified species

Formicidae

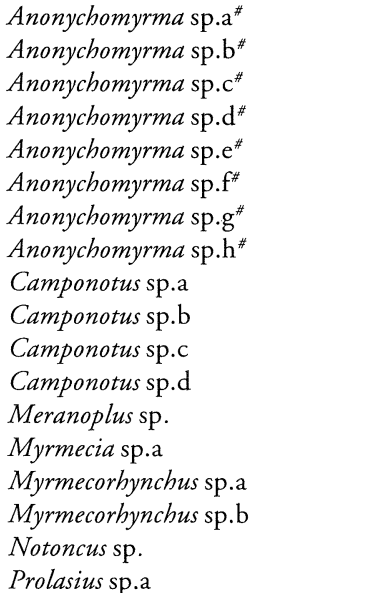




\section{APPENDIX 1 cont.}

Prolasius sp.b

Rhytidoponera sp.a

Stigmacros sp.a

Stigmacros sp. $\mathrm{b}^{\#}$

7 unidentified species

Ichneumonidae

28 unidentified species

Megalyridae

1 unidentified species

Megastigmidae

13 unidentified species

Mutillidae

Ephutomorpha dorsigera (Westwood)

Pergidae

Lophyrotoma interrupta (Klug)

Perga affinis insularis Riek

Pergagrapta bella (Newman)

Pseudoperga lewisii (Westwood)

Platygasteridae

2 unidentified species

Pompilidae

2 unidentified species

Proctotrupidae

6 unidentified species

Scoliidae

1 unidentified species

Sphecidae

1 unidentified species

Tenthredinidae

1 unidentified species

Tiphiidae

7 unidentified species

Lepidoptera

Anthelidae

Anthela acuta (Walker)

Anthela nicothoe (Boisduval)

Anthela ocellata (Walker)

Anthela sp.a

Anthela sp.b

Pterolocera amplicornis Walker

Pterolocera sp.a

Arctiidae

Castulo doubledayi (Newman)

Nyctemera amica (White)

Palaeosia bicosta (Walker)

Phaeophlebosia furcifera Walker

Scoliacma bicolora Boisduval

Spilosoma glatignyi (Le Guillou)

Utetheisa pulchelloides Hampson

Cossidae

Culama australis Walker

Cosmopterigidae Macrobathra sp.

Gelechiidae

Protolechia sp.

Geometridae

Boarmia lyciaria (Guenee)

Boarmia sp a

Boarmia sp.b

Capusa senilis Walker

Chlenias sp.

Chlorocoma dichloraria (Guenee)

Chlorodes boisduvalaria (Le Guillou)

Chrysolarentia vicissata (Guenee)

Cleora bitaeniaria (Le Guillou)

"Cidaria" subochraria Doubleday*

Crypsiphona ocultaria (Donovan)

Dichromodes ainaria Guenee

Ectropis excursaria (Guenee)

Ectropis exsuperata (Walker)
Eucyclodes buprestaria Guenee

Euloxia meandraria (Guenee)

Gastrinodes bitaeniaria (Le Guillou)

Heliomystis electrica Meyrick

Hypobapta eugramma (Low.)*

Hypobapta percomptaria (Guenee)

Melanodes anthracitaria Guenee

Microdes squamulata Guenee

Mnesampela comarcha Meyrick

Mnesamplela privata (Guenee)

Monoctenia falernaria Guenee

Niceteria macrocosma (Low.)*

Paralaea beggaria Guenee

Plesanemma fucata (Felder \& Rogenhofer)

Stathmorrhopa berberi (Turner)

Thalaina inscripta Walker

Thalaina selenaea Doubleday

36 unidentified species

Gracillariidae

Acrocercops laciniella (Meyrick)

1 unidentified species

Heliozelidae

Heliozela sp.

1 unidentified species

Hepialidae

Abantiades latipennis Tindale

Abantiades sp.a

Aenetus ligniveren (Lewin)

Fraus latistria Nielsen \& Kristensen

Oncopera intricata Walker

Oxycanus sordidus Herrich-Schaffer

Trictena argentata Herrich-Schaffer

Hypertrophidae

Hypertropha tortriciformis (Guenee)

Lasiocampidae

Digglesia australasiae (Fabricius)

Digglesia sp.a

Entometa fervens (Walker)

Opsirbina albigutta (Walker)

Pernattia exposita (Lewin)

1 unidentified species

Limacodidae

Doratifera pinguis (Walker)

Lycaenidae

Neolucia hobartensis (Miskin)

Paralucia aurifer (Blanchard)

Lymantriidae

Acyphas leucomelas (Walker)

Teia anartoides Walker

Noctuidae

Agrotis infusa (Boisduval)

Agrotis porphyricollis Guenee

Amphipyra sanguinipuncta Guenee Dasygaster nephelistis Hampson

Dasygaster padockina (Le Guillou)*

Diarsia intermixta (Guenee)

Euplexia sp.

Eutrichopidia latinus (Donovan)

Helicoverpa punctigera (Wallengren)

Heliothis rubrescens (Walker)

Neumichtis sepultrix (Guenee)

Nola aulacota Meyrick

Pantydia sparsa Guenee

Persectania ewingii (Westwood)

Praxis edwardsii Guenee

Praxis sp.

Rhapsa suscitalis (Walker)

Rictonis atra (Guenee)

Rictonis gypsina*

Rictonis sp. nr.flexirena (Walker)

Rictonis sp. 


\section{APPENDIX 1 cont.}

Sideridis costalis (Walker) Uraba lugens Walker

Notodontidae

Danima banksiae (Lewin)

Hylaeora inclyta (Walker)

Sorama bicolor Walker

Nymphalidae

Argynnina hobartia (Westwood)

Geitoneura klugi (Guerin-Meneville)

Heteronympha merope (Fabricius)

Heteronympha penelope Waterhouse

Junonia villida (Fabricius)

Vanessa kershawi (McCoy)

Oreixenica lathoniella (Westwood)

Oecophoridae

Agriophara sp.

Artiastis sp.

Cryptophasa albacosta Lewin

Garrha callianassa (Meyrick)

Machimia parthenopa (Meyrick)

Oenochroasp.

Stathmopoda cephalaea Meyrick

Wingia lambertella (Wing)

Pieridae

Pieris rapae (Linnaeus)

Psychidae

Clania sp.

Lepidoscia arctiella Walker

Naryciasp.

Pyralidae

Gauna aegusalis (Walker)

Hednota sp.

Macalla sp.

Uresiphita ornithopteralis (Guenee)

Saturniidae

Opodiphthera helena (White)

Sphingidae

Hippotion scrofa (Boisduval)

Thaumetopoeidae

Epicoma melanospila (Wallengren)

Trichiocercus mesomelas (Walker)*

Tortricidae

Acropolitis ptychosema Turner

Epiphyas ashworthana (Newman)

Epiphyas plastica (Meyrick)

Epiphyas postvittana (Walker)

Epiphyas sp.

Palaeotoma styphelana Meyrick

2 unidentified species

Zygaenidae

Pollanisus viridipulverulentus Guerin-Meneville

Mantodea

Mantidae

Orthodera ministralis (Fabricius)

Mecoptera

Bittacidae

Harpobittacus australis Klug

Neuroptera

Chrysopidae

Chrysopa edwardsi Banks

Hemerobiidae

Drepanacra binocula (Newman)

Mantispidae

Calomantispa venusta Lambkin

Campion australasiae (Guerin)

Campion callosus Lambkin
Odonata

Corduliidae

1 unidentified species

Gomphidae

Austrogomphus guerini (Rambur)

Orthoptera

Acrididae

Austroicetes sp.

Gastrimargus musicus (Fabricius)

Phaulacridium vittatum (Sjostedt)

Russalpia albertisi (Bolivar)

Tasmaniacris tasmaniensis (Bolivar)

3 unidentified species

Tettigoniidae

Acripeza reticulata Guerin

1 unidentified species

Plecoptera

Gripopterygidae

3 unidentified species

Notonemouridae

Kimminosperla sp.

Spaniocercasp.

1 unidentified species

Psocoptera

Caeciliidae

Caecilius semifuscatus (Tillyard)

Caecilius sp.

Ectopsocidae

Ectopsocus briggsi McLachlan

Peripsocidae

Peripsocus sp.

Philotarsidae

Haplophallus paraguttatus (Tillyard)*

Haplophallus sp.

1 unidentified species

Thysanoptera

Phlaeothripidae

9 unidentified species

Trichoptera

Hydropsychidae

1 unidentified species

* Indicates species not listed in the Tasmanian insect fauna as listed by Semmens et al. 1992.

\# Indicates undescribed 'new' species. 
APPENDIX 2

Insect/host plant associations*

\begin{tabular}{|c|c|c|c|c|c|c|c|c|c|c|c|c|c|c|c|c|c|c|c|c|c|c|c|}
\hline & & 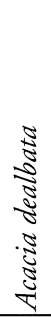 & 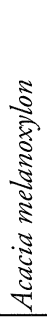 & 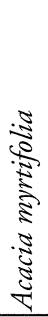 & 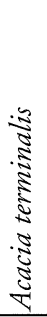 & 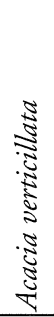 & 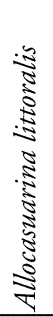 & 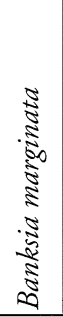 & 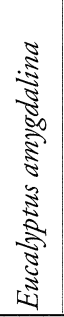 & 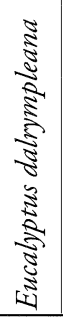 & 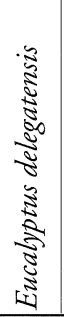 & 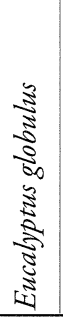 & 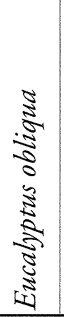 & 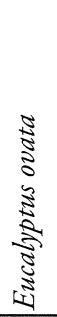 & 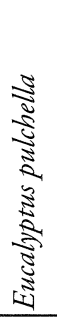 & 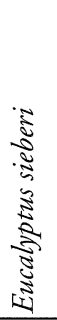 & 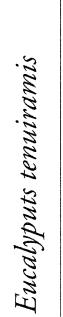 & 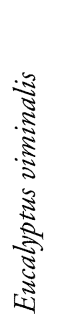 & 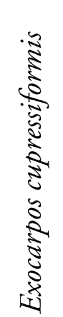 & 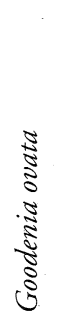 & 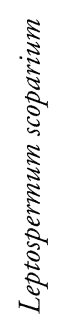 & 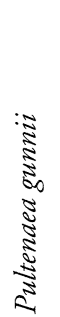 & 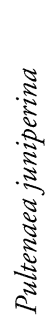 \\
\hline & & 1 & 2 & 3 & 4 & 5 & 6 & 7 & 8 & 9 & 10 & 11 & 12 & 13 & 14 & 15 & 16 & 17 & 18 & 19 & 20 & 21 & 22 \\
\hline Acrididae & Phaulacridium vittatum & & & & & & & & & & + & & $+^{*}$ & & & & & & & & & & \\
\hline \multirow[t]{3}{*}{ Anthelidae } & Anthela sp. a & + & & & & & & & & & & & & & & & & & & & & & \\
\hline & Anthela sp. b & & & & & & & & & & & & & & & & & + & & & & & \\
\hline & Pterolocera sp. & $t^{*}$ & & & & & & & & & & & & & & & & & & & & & \\
\hline Bostrychidae & Xylion collaris & & & & & & & $+^{*}$ & & & & & $+^{*}$ & & & & & $t^{*}$ & & & & & \\
\hline \multirow[t]{7}{*}{ Cerambycidae } & Ancita marginicollis & + & & & & & & & & & & & & & & & & & & & & & \\
\hline & Bethelium signiferum & $+^{*}$ & & & & & & & & & & & & & & & & & & & & & \\
\hline & Coptocercus rubripes & & & & & & & & $+*$ & & & & $+^{*}$ & & & $+^{*}$ & & $+^{*}$ & & & & & \\
\hline & Epithora dorsalis & & & & & & & & $+^{*}$ & & & & $+^{*}$ & & & $+^{*}$ & & $+^{*}$ & & & & & \\
\hline & Pytheus erosus & & & & & & & & & & & & $+^{*}$ & & & & & & & & & & \\
\hline & Toxeutes sp. & & & & & & & & & & & & $+^{*}$ & $t^{*}$ & & & & & & & & & \\
\hline & Zoedia divisa & $t^{*}$ & & & & & & & & & & & & & & & & & & & & & \\
\hline \multirow[t]{16}{*}{ Chrysomelidae } & Acacicola hamadryas & + & & & & & & & & & & & & & & & & & & & & & \\
\hline & Acacicola orphana & + & & & & + & & & & & & & & & & & & & & & & & \\
\hline & Acacicola sp. b & & & & & & & & & & & & & & & & & & & & & + & + \\
\hline & Cadmus australis & & & & & & & & + & & & $+^{*}$ & $+^{*}$ & & $+^{*}$ & & & & & & & & \\
\hline & Cadmus crinicollis & & & & & & & & & & & & & & & + & & + & & & & & \\
\hline & Cadmus strigillatus & & & & & & & & & & & & 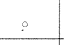 & & $t^{*}$ & & & & & & & & \\
\hline & Cadmus sp. 4 & & & & & & & & + & + & & & & & + & + & & + & & & & & \\
\hline & Cadmus sp. a & & & & & & & & + & & & & & & & & & & & & & & \\
\hline & Chrysophtharta aurea & & & & & & & & + & & & & & & & $+^{*}$ & & + & & & & & \\
\hline & Chrysophtharta bimaculata & & & & & & & & & & + & $+^{*}$ & $t^{*}$ & & & & & & & & & & \\
\hline & Chrysophtharta crucata & & & & & & & & & & & & & & + & & & & & & & & \\
\hline & Chrysophtharta decolorata & & & & & & & & + & & & & & & + & & $+^{*}$ & & & & & & \\
\hline & Chrysophtharta nobilitata & & & & & & & & + & + & & & + & & + & + & + & + & & & & & \\
\hline & Chrysophtharta philomela & & & & & & & & & & + & & & & & & & & & & & & \\
\hline & Chrysophtharta variicollis & & & & & & & & + & & + & & + & + & + & & & + & & & & & \\
\hline & Chrysophtharta sp. a & & & & & & & & + & & & & & & & & & & & & & & \\
\hline
\end{tabular}


APPENDIX 2 cont.

\begin{tabular}{|c|c|c|c|c|c|c|c|c|c|c|c|c|c|c|c|c|c|c|c|c|c|c|c|}
\hline & & 1 & 2 & 3 & 4 & 5 & 6 & 7 & 8 & 9 & 10 & 11 & 12 & 13 & 14 & 15 & 16 & 17 & 18 & 19 & 20 & 21 & 22 \\
\hline & Chrysophtharta sp. c & & & & & & & & & & & & + & & + & & & & & & & & \\
\hline & Chrysophtharta sp. $\mathrm{h}$ & & & & & & & & + & & & & & & & & & & & & & & \\
\hline & Haltica pagana & + & & & & & & & & & & & & & & & & & & & & & \\
\hline & Nascio parryi & & & & & & & & & & & $+^{*}$ & & & & & & & & & & & \\
\hline & Paropsides umbrosa & + & & & & & & & & & & & & & & & & & & & & & \\
\hline & Paropsis aegrota elliottii & & & & & & & & + & & + & & + & & & + & & & & & & & \\
\hline & Paropsis deboeri & & & & & & & & + & & & & + & & & & + & + & & & & & \\
\hline & Paropsis dilatata & & & & & & & & + & & & & $+^{*}$ & & & & $t^{*}$ & & & & & & \\
\hline & Paropsis porosa & & & & & & & & + & + & & + & + & $+^{*}$ & & + & + & + & & & & & \\
\hline & Paropsis tasmanica & & & & & & & & & & & $+^{*}$ & + & & & & & + & & & & & \\
\hline & Paropsis sp. a & & & & & & & & & & & & & & & & & + & & & & & \\
\hline & Paropsisterna nucea & & & & & & & & & + & & & $t^{*}$ & & & & & + & & & & & \\
\hline & Trachymela papulosa & & & & & & & & $+^{*}$ & & $+^{*}$ & & + & $+^{*}$ & & & & & & & & & \\
\hline & Trachymela rugosa & & & & & & & & + & + & $t^{*}$ & & $+^{*}$ & & + & + & & + & & & & & \\
\hline Cicadidae & Cicadetta torrida & + & & & & & & & & & & $t^{*}$ & & & & + & & & & & & & \\
\hline Cicadellidae & Tenuitartessus blundellensis & & & & & & & & $+^{*}$ & & & & & & $+^{*}$ & & & . & & & & & \\
\hline \multirow[t]{2}{*}{ Coreidae } & Amorbus obscuricornis & & & & & & & & + & + & + & & + & & + & + & + & + & & & & & \\
\hline & Gelonus tasmanicus & & & & & & & & + & & + & & + & & & + & & + & & & & & \\
\hline \multirow[t]{10}{*}{ Curculionidae } & Acalonoma pusilla & & & & & & & & & & & & & & & & & & & $t^{*}$ & & & \\
\hline & Belus bidentatus & $+^{*}$ & & & & & & & & & & & & & & & & & & & & & \\
\hline & Belus bimaculatus & $t^{*}$ & & & & & & & & & & & & & & & & & & & & & \\
\hline & Gonipterus gibberus & & & & & & & & & $\circ$ & & & & & & + & & + & & & & & \\
\hline & Gonipterus lepidotus & & & & & & & & + & & & & & & & & & & & & & & \\
\hline & Gonipterus scutellatus & & & & & & & & + & + & + & + & + & + & + & + & + & + & & & & & \\
\hline & Merimnetes sp. & & & & & & & & + & + & & & & & & & & + & & & & & \\
\hline & Rachiodes bicaudatus & & & & & & & & & & & $+^{*}$ & & & & & & + & & & & & \\
\hline & Rachiodes multidentatus & & & & & & & & + & & + & + & & & & & & & & & & & \\
\hline & Rhadinosomus lacordairei & & & & & & & & & + & & & & & & & & & & & & & \\
\hline . & Syarbis alcyone & & & & & & & & & & & & + & & & + & & & & & & & \\
\hline Eriococcidae & Eriococcus coriaceous & & & & & & & & + & & + & + & + & & + & + & & + & & & & & \\
\hline Eurymelidae & Eurymeloides bicincta & & & & & & & & $t^{*}$ & & & & & & & & & & & & & & \\
\hline Gelechiidae & Protolechia sp. & & & & & & & & & + & + & & & & + & & & & & & & & \\
\hline \multirow[t]{7}{*}{ Geometridae } & Boarmia sp. & $+^{*}$ & & & & & & & & & & & & & & & & & & & & & \\
\hline & Capusa senilis & & & & & & & & $+^{*}$ & & & & & & & & & $t^{*}$ & & & & & \\
\hline & Chlenias sp. & + & & & & & & & + & & + & & & & & & & & & + & & & \\
\hline & Chlorocoma dichloraria & $t^{*}$ & & & & & & & & & & & & & & & & & & & & & \\
\hline & Chlorodes boisduvalia & & & & & & & & & & & & & & & & & & & & + & & \\
\hline & Cleora bitaeniaria & & & & & & & & + & & & & & & & & & & & & & & \\
\hline & Crypsiphona occultaria & & & & & & & & + & & & & $+^{*}$ & & & & & & & & & & \\
\hline
\end{tabular}


APPENDIX 2 cont

\begin{tabular}{|c|c|c|c|c|c|c|c|c|c|c|c|c|c|c|c|c|c|c|c|c|c|c|c|}
\hline & & 1 & 2 & 3 & 4 & 5 & 6 & 7 & 8 & 9 & 10 & 11 & 12 & 13 & 14 & 15 & 16 & 17 & 18 & 19 & 20 & 21 & 22 \\
\hline & Dichromodes ainaria & $+^{*}$ & & & & & & & & & & & & & & & & & & & & & \\
\hline & Ectropis excursaria & & & & & & & & & & & & & & & & & & $t^{*}$ & & & & \\
\hline & Euloxia meandraria & & & & & & & & $t^{*}$ & & & & & & & & & & & & & & \\
\hline & Hypobapta percomptaria & & & & & & & & + & & & & & & & & & & & & & & \\
\hline & Microdes squamulata & $t^{*}$ & & & & & & & & & & & & & & & & & & & & & \\
\hline & Mnesampela comarcha & & & & & & & & & $+^{*}$ & & & $t^{*}$ & & & & & $+^{*}$ & & & & & \\
\hline & Mnesampela privata & & & & & & & & & + & + & + & & & & & + & & & & & & \\
\hline & Monoctenia falernaria & & & & & & & & & & & & $+^{*}$ & & & & & & & & & & \\
\hline & Stathmorrhopa berberi & & & & & & & & $+^{*}$ & & & & & & & & & & & & & & \\
\hline & Thalaina inscripta & $+^{*}$ & & & & & & & & & & & & & & & & & & & & & \\
\hline & Thalaina selenaea & & $t^{*}$ & & & & & & & & & & & & & & & & & & & & \\
\hline Gracillariidae & Acrocercops sp. & & & & & & & & + & + & + & & + & & & + & & + & & & & & \\
\hline Heliozelidae & Heliozela prodela & & & & & & & & & & & & + & & & & & & & & & & \\
\hline Hepialidae & Aenetus ligniveren & & & & & & & & & & & & $+^{*}$ & & & & & & & & & & \\
\hline Lasiocampidae & Pernattia exposita & & & & & & + & & & & & & & & & & & & & & & & \\
\hline Limacodidae & Doratifera pinguis & & & & & & & & $+^{*}$ & & + & & & & & + & & $+^{*}$ & & & & & \\
\hline \multirow{2}{*}{ Lymantriidae } & Acyphas leucomelas & + & + & & & & & & + & & + & & & & & & & & $+^{*}$ & & & & \\
\hline & Teia anartoides & $t^{*}$ & & & & & & & $t^{*}$ & & & & $t^{*}$ & & & & & & + & & & & \\
\hline Lyonetiidae & Stegommata sufuratella & & & & & & & + & & & & & & & & & & & & & & & \\
\hline Machaerotidae & Chaetophyes compacta & & & & & & & & + & + & + & & + & & & + & + & + & & & & & \\
\hline Membracidae & Daunus tasmaniae & $+^{*}$ & & & & & & & & & & & & & & & & & & & & & \\
\hline \multirow{2}{*}{ Noctuidae } & Leucania eugrapha & & & & & & & & $t^{*}$ & & & & & & & & & & & & & & \\
\hline & Uraba lugens & & & & & & & & + & + & + & + & + & & + & + & + & + & & & & & \\
\hline \multirow[t]{4}{*}{ Notodontidae } & Danima banksiae & & & & & & & $t^{*}$ & & & & & & & & & & & & & & & \\
\hline & Hylaeora inclyta & & & & & & & & & $+^{*}$ & & & & & & & & & & & & & \\
\hline & Sorama bicolor & & & & & & & & & & & & $+^{*}$ & & & & & & & & & & \\
\hline & Trichocerus mesomelas & & & & & & & & $+^{*}$ & & & & $t^{*}$ & & & & & & & & & & \\
\hline \multirow[t]{4}{*}{ Oecophoridae } & Garrha callianassa & & & & & & & + & & & & & & & & & & & & & & & \\
\hline & Hypertropha tortriciformis & & & & & & & & & & + & & + & & & & & + & & & & & \\
\hline & Machimia parthenopa & & & & & & & & $+^{*}$ & & & $t^{*}$ & & & & & & & & & & & \\
\hline & Oenochroa sp. & & & & & & & & + & & & & & & & & & & & & & & \\
\hline \multirow[t]{4}{*}{ Pergidae } & Lophyrotoma interrupta & & & & & & & & & & & & & & & + & & & & & & & \\
\hline & Perga affinis insularis & & & & & & & & & & & $+^{*}$ & + & & & & & & & & & & \\
\hline & Pergagrapta bella & & & & & & & & + & & & & & & & & & & & & & & \\
\hline & Pseudoperga lewisii & & & & & & & & + & & & & & & & & & + & & & & & \\
\hline \multirow[t]{3}{*}{ Psychidae } & Clania sp. & & & & & & & & + & & & & & & & & & & & & & & \\
\hline & Lepidoscia arctiella & + & & & & & & & + & & & & & & & & & & & & & & \\
\hline & Narycia sp. & & & & & & & & & & & & + & & & + & & & & & & & \\
\hline Psyllidae & Acizzia acaciaedealbata & + & & & & & & & & & & & & & & & & & & & & & \\
\hline
\end{tabular}


APPENDIX 2 cont.

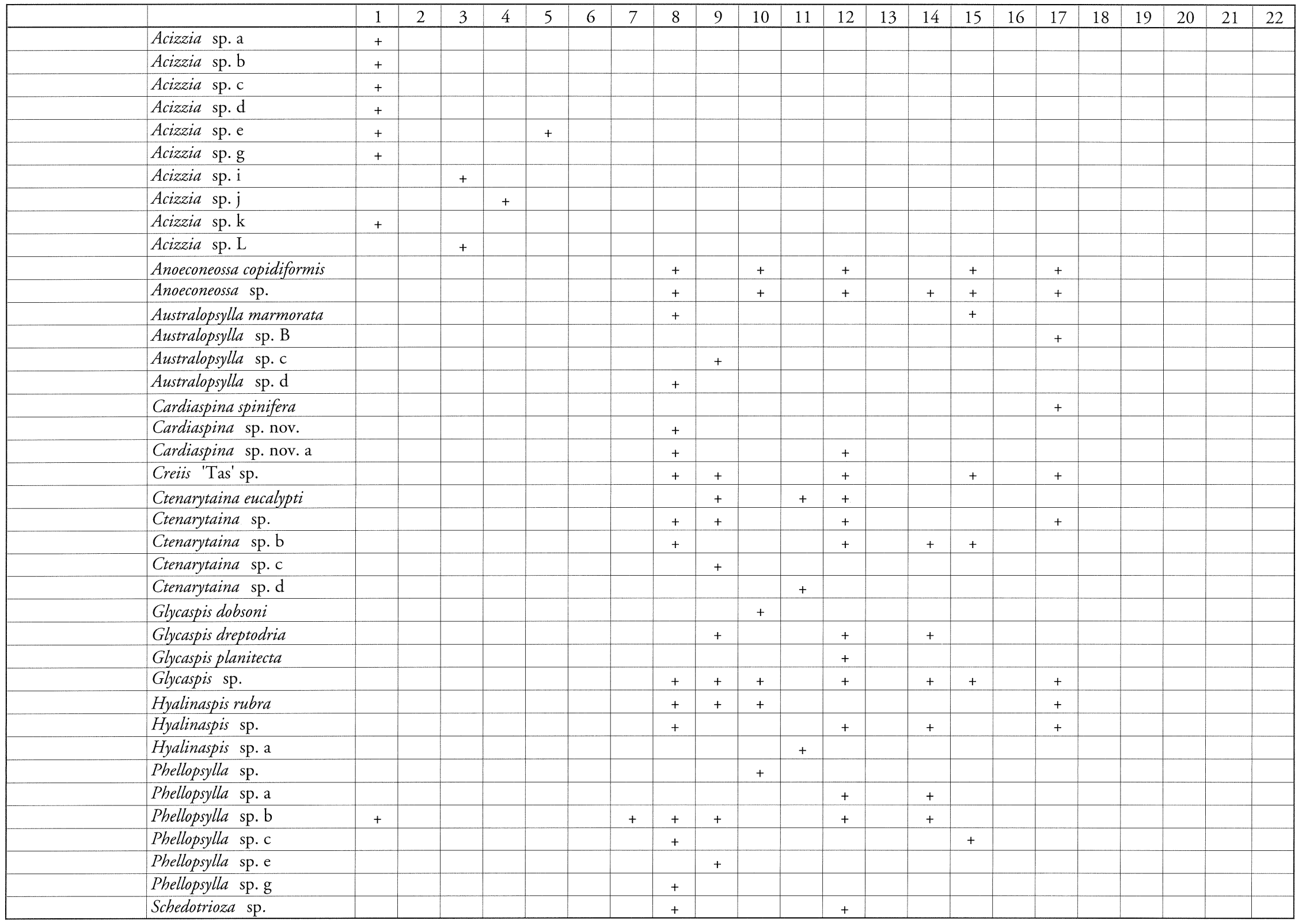




\begin{tabular}{|c|c|c|c|c|c|c|c|c|c|c|c|c|c|c|c|c|c|c|c|c|c|c|c|}
\hline & & 1 & 2 & 3 & 4 & 5 & 6 & 7 & 8 & 9 & 10 & 11 & 12 & 13 & 14 & 15 & 16 & 17 & 18 & 19 & 20 & 21 & \\
\hline & Schedotrioza sp. a & & & & & & & & + & & & & & & & & & & & & & & \\
\hline & Schedotrioza sp. b & & & & & & & & & + & & & & & & & & & & & & & \\
\hline & Schedotrioza sp. c & & & & & & & & & + & & & + & & & & & & & & & & \\
\hline & Schedotrioza sp. i & & & & & & & & + & & & & & & & & & + & & & & & \\
\hline & Trioza sp. b & & & & & & + & & & & & & & & & & & & & & & & \\
\hline & Trioza sp. c & & & & & & + & & & & & & & & & & & & & & & & \\
\hline & Trioza sp. $\mathrm{d}$ & & & & & & + & & & & & & & & & & & & + & & & & \\
\hline \multirow[t]{2}{*}{ Pyralidae } & Gauna aegusalis & $+^{*}$ & & & & & & & & & & & & & & & & & & & & & \\
\hline & Macalla sp. & & & & & & & & & & & & & & & & & & & & + & & \\
\hline Saturniidae & Opodiphthera helena & & & & & & & & + & + & & & $+*$ & & & & & $+*$ & & & & & \\
\hline \multirow[t]{9}{*}{ Scarabaeidae } & Diphucephala colaspidoides & $+^{*}$ & & & & & & & & & & & & & & & & & & & & & \\
\hline & Heteronyx crinitus & & & & & & & & + & & + & & & & & & & & & & & & \\
\hline & Heteronyx sp. a & & & & & & & & + & + & + & & + & & & & & + & & & & & \\
\hline & Heteronyx sp. b & & & & & & & & & & & & & & & & & + & & & & & \\
\hline & Heteronyx sp.c & & & & & & & & + & & & & + & & & + & & & & & & & \\
\hline & Liparetus atratus & & & & & & & & & & & & + & & & & & + & & & & & \\
\hline & Liparetus convexus & & & & & & & & & $+^{*}$ & & & + & & + & & & & & & & & \\
\hline & Phyllotocus erythropterus & & & & & & & & & & & & & & & & & & & & + & & \\
\hline & Xylonychus pilifer & & & & & & & & $+^{*}$ & & & & 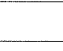 & & & + & & & & & & & \\
\hline Stenomatidae & Agriophara sp. & & & & & & & & & & & & + & & & & & & & & & & \\
\hline Thaumetopoeidae & Epicoma melanospila & & & & & & & & + & & & & $+^{*}$ & & $t^{*}$ & & & $t^{*}$ & & & & & \\
\hline Tingidae & Epimixia sp. & + & & & & & & & + & + & & & + & & & & & & & & & & \\
\hline \multirow[t]{4}{*}{ Tortricidae } & Acropolitis ptychosema & & & & & & & & $+^{*}$ & & $+^{*}$ & & + & & & & & & & & & & \\
\hline & Epiphyas ashworthana & $+^{*}$ & & & & & & & & & & $+^{*}$ & & & & & & & & & & & \\
\hline & Epiphyas postvittana & & & & & & & & & & & & $+*$ & & & & & & & & & & \\
\hline & Palaeotoma styphelana & & & & & & & & $+^{*}$ & & & + & $+^{*}$ & & & & & + & & & & & \\
\hline TOTALS & & 35 & 2 & 2 & 1 & 2 & 4 & 5 & 74 & 33 & 30 & 19 & 64 & 5 & 24 & 31 & 10 & 46 & 4 & 2 & 3 & 1 & 1 \\
\hline & & & & & & & & & & & & & & & & & & & & & & & \\
\hline
\end{tabular}

* Species with known hosts as indicated but not actually feeding when collected. 